\begin{tabular}{|c|c|}
\hline $\begin{array}{l}\text { Additional } \\
\text { Information }\end{array}$ & $\begin{array}{l}\text { NOTICE: This is the author's version of a work that was accepted for } \\
\text { publication in Electrochima Acta. Changes resulting from the publishing } \\
\text { process, such as peer review, editing, corrections, structural formatting, } \\
\text { and other quality control mechanisms may not be reflected in this } \\
\text { document. Changes may have been made to this work since it was } \\
\text { submitted for publication. A definitive version was subsequently } \\
\text { published in Electrochima Acta, } 77,2012 \text {. DOI: } \\
10.1016 / \mathrm{j} \text {.electacta.2012.05.070 }\end{array}$ \\
\hline $\begin{array}{l}\text { Alternative } \\
\text { Location }\end{array}$ & http://dx.doi.org/ 10.1016/j.electacta.2012.05.070 \\
\hline
\end{tabular}




\title{
Electrochemical behaviour of myoglobin at an array of microscopic liquid-liquid
}

\section{interfaces}

\author{
Shane O’Sullivan ${ }^{1}$, Damien W. M. Arrigan ${ }^{1 *}$ \\ Nanochemistry Research Institute, Department of Chemistry, Curtin University, GPO Box U1987, \\ Perth, WA 6845, Australia.
}

*Corresponding author: Email d.arrigan@curtin.edu.au Tel: +61 0892669735

\begin{abstract}
Electrochemistry at liquid-liquid interfaces, or at interfaces between two immiscible electrolyte solutions (ITIES), provides a basis for the non-redox detection of biological molecules, based on iontransfer or adsorption processes. The electroactivity of myoglobin at an array of micron-sized liquidorganogel interfaces was investigated. The $\mu$ ITIES array was patterned with a silicon membrane consisting of an array of eight pores with radii of $\sim 12.8 \mu \mathrm{m}$ and a pore to pore separation of $\sim 400 \mu \mathrm{m}$. Using cyclic voltammetry at the ITIES, the protein was shown to adsorb at the interface and facilitate the transfer of the organic phase electrolyte anions to the aqueous side of the interface. The electrochemical current response was linear with concentration in the range of $1-6 \mu \mathrm{M}$, with corresponding surface coverage of $10-50 \mathrm{pmol} \mathrm{cm} \mathrm{cm}^{-2}$. The reverse peak currents was found to be proportional to the voltammetric scan rate, indicating a desorption process. The detection of the protein was only possibly when the $\mathrm{pH}$ of the aqueous phase solution was below the $\mathrm{pI}$ of the protein. The steady-state simple ion transfer behaviour of tetraethylammonium cation was decreased on the forward sweep, providing a qualitative indication of the presence of adsorbed protein at the interface. Increasing the ionic strength of the aqueous phase resulted in enhanced peak currents, possibly due to aggregation of protein precipitates in the aqueous solution. UV/Vis absorbance spectroscopy was used

${ }^{1}$ ISE Member.
\end{abstract}


to investigate the effects of various aqueous electrolyte solutions on the structure of the protein, and it was shown that at low $\mathrm{pH}$ the protein is at least partially denatured. These results provide the basis for label-free detection of myoglobin at the ITIES.

Keywords: myoglobin, voltammetry, ITIES, liquid-liquid interface, adsorption.

\section{Introduction}

In this report, the electroactivity of myoglobin $(\mathrm{Mb})$ at the interface between two immiscible electrolyte solutions (ITIES) [1] is presented. Mb is a globular protein containing a haem group, comprised of a single chain of 153 amino acids with a molecular mass of $16.7 \mathrm{kDa}$ and an iso-electric point of $\sim 7.3$ [2]. It was the first protein to have its 3D crystal structure determined, in 1958 [3]. Mb is an oxygen-binding protein used in the transportation and storage of $0_{2}$ in muscle cells [4]. The detection of $\mathrm{Mb}$ may be a route to the diagnosis of acute myocardial infarction (AMI), as elevated concentrations of $\mathrm{Mb}$ are present in the blood following the onset of the disease [5,6]. Elevated concentrations of $\mathrm{Mb}(4-11 \mathrm{nM})$ are present as early 1-3 hours after AMI [7], which implies that a rapid, accurate and reliable testing method is needed. The detection of Mb within these first few hours allows $\mathrm{Mb}$ to be used as an early confirmation of AMI and has the potential to impact fundamentally on medical therapy [8].

Electrochemistry at the ITIES provides a strategy for the label-free detection of molecules that are not easily detected by conventional redox methods at solid electrodes $[9,10]$. To improve the performance characteristics of electrochemistry at the ITIES, the miniaturisation of the interface has been a topic of interest since the report of the first micron-sized ITIES by Taylor and Girault in 1986 [11]. The use of $\mu$ ITIES minimises problems occurring at larger $(\mathrm{mm}$ or $\mathrm{cm})$ interfaces such as charging current and ohmic potential drop while also significantly increasing mass transport rates $[12,13]$. The development of nanoscale interfaces has received much attention recently, in an attempt to further improve the electrochemical response at the ITIES [13-15]. Methods for development of the 
micro/nano ITIES vary from pulled glass pipettes [11], laser ablation of a substrate [16] to various chemical etching methods [17]. The results reported here utilised a $\mu$ ITIES array fabricated from a silicon membrane containing an array of micropores [18]. In recent years there have been many reports on the behaviour and detection of biomolecules at the ITIES. The detection of a range of biomolecules including amino acids[19], heparin[20, 21], protamine[22, 23], haemoglobin[24, 25], lysozyme[26, 27], insulin[28], dopamine[29-31], noradrenaline[31] and DNA[32] have been reported at the ITIES.

Osakai et al. used surfactants in the organic phase as the basis for protein detection and found that cytochrome c could be transferred across the ITIES [33-35]. A range of proteins have been studied at the ITIES in the absence of surfactants and it was found that the proteins did not transfer across the ITIES but adsorbed there and facilitated the transfer of the organic anion to the aqueous phase [24, 2628]. The effect of varying the organic phase anion on the electrochemistry of protamine at the ITIES was extensively studied by Trojanek et al. using conductometry, voltammetry and quasi-elastic light scattering [22]. The interactions of cationic proteins with the hydrophobic anions has been verified also by on-line acoustic sensor[36] and mass spectrometric[37] methods.

The aim of the work presented in this paper was to investigate the behaviour of Mb at the $\mu$ ITIES array and to make comparisons to previous work. In particular, it was of interest to see if the previously proposed mechanism for protein detection was generic: the adsorption of protein and facilitated iontransfer of hydrophobic anion applies to haemoglobin[24, 25], lysozyme[26, 27, 37] and insulin[28] [27]; will it also apply to Mb? Although some behaviour of Mb at the ITIES was reported[35], that work was based on experiments in the presence of organic phase surfactant. In the present work, the behaviour of $\mathrm{Mb}$ was characterised by cyclic voltammetry at the interface between the liquid aqueous phase and the gelled organic phase. The organogel was located within the pores of the silicon membrane used, so that the interface was inlaid. This arrangement results in radial diffusion to the interface from the aqueous side of the interface and linear diffusion from the organic side of the interface $[18,38]$. 


\section{Experimental details}

2.1 Reagents. All the reagents were purchased from Sigma-Aldrich Australia Ltd. and used as received, unless indicated otherwise. The gelled organic phase was prepared using bis(triphenylphosphoranylidene) tetrakis(4-chlorophenyl)borate ( $\left.\mathrm{BTPPA}^{+} \mathrm{TPBCl}^{-}, 10 \mathrm{mM}\right)$ in 1,6dichlorohexane (1,6-DCH) and low molecular weight poly(vinyl chloride) (PVC) [39]. The organic phase electrolyte salt $\mathrm{BTPPA}^{+} \mathrm{TPBCl}^{-}$was prepared by metathesis of bis(triphenylphosphoranylidene)ammonium chloride $\left(\mathrm{BTPPA}^{+} \mathrm{Cl}^{-}\right)$and potassium tetrakis(4chlorophenyl) borate $\left(\mathrm{K}^{+} \mathrm{TPBCl}^{-}\right)[40]$. Aqueous stock solutions of Myoglobin (from equine heart) were prepared in $10 \mathrm{mM} \mathrm{HCl}$ or in mixtures of 1,10 or $100 \mathrm{mM} \mathrm{LiCl}$ in $10 \mathrm{mM} \mathrm{HCl}(\mathrm{pH} 2)$ on a daily basis and stored at $+4{ }^{\circ} \mathrm{C}$. For variable $\mathrm{pH}$ experiments, the $\mathrm{pH}$ was adjusted using solutions of $10 \mathrm{mM} \mathrm{HCl}$ and $10 \mathrm{mM} \mathrm{LiOH}$. Tetraethyl ammonium $\left(\mathrm{TEA}^{+}\right)$chloride solutions were prepared in a background electrolyte of $10 \mathrm{mM} \mathrm{HCl}$. All the aqueous solutions were prepared in purified water (resistivity: 18 $\mathrm{M} \Omega \mathrm{cm}$ ) from a USF Purelab Plus UV.

2.2 Apparatus. All electrochemical experiments were performed using an Autolab PGSTAT302N electrochemical analyser (Metrohm Autolab, Utrecht, The Netherlands), controlled by the NOVA software supplied with the instrument. The micropore arrays were fabricated from silicon membranes using photolithographic patterning and a combination of wet and dry silicon etching [18]. The fabrication procedure provided hydrophobic micropore walls allowing the organic phase to fill the pores. The micropore array consisted of eight micropores in a hexagonal close-packed arrangement, each with a diameter of $12.8 \mu \mathrm{m}$ and a pore centre-to-centre distance of $400 \mu \mathrm{m}$. The microporous silicon membranes were sealed onto the lower orifice of a glass cylinder using silicone rubber (Acetic acid curing Selleys glass silicone). The gelled organic phase solution was introduced into the silicon micropore arrays via the glass cylinder, and the organic reference solution was placed on top of the gelled organic phase. The silicon membrane was then inserted into the aqueous phase $(10 \mathrm{mM} \mathrm{HCl}$, Myoglobin in $10 \mathrm{mM} \mathrm{HCl}$ or 1,10 or $100 \mathrm{mM} \mathrm{LiCl}$ and/or $\mathrm{TEA}^{+}$in $10 \mathrm{mM} \mathrm{HCl}$ ). Voltammetric experiments were performed next, as previously described [26]. Ultraviolet/visible (UV/vis) 
absorbance spectroscopy was carried out using a Perkin-Elmer Lambda 35 instrument. The instrument was scanned in the wavelength range of $250 \mathrm{~nm}$ to $500 \mathrm{~nm}$ at the rate of $480 \mathrm{~nm} \mathrm{~min}{ }^{-1}$. The slit width was $1 \mathrm{~nm}$ with a resolution of $1 \mathrm{~nm}$. The sample was run in a $1 \mathrm{x} 1 \mathrm{~cm}$ quartz cuvette.

2.3 Electrochemical cell. The setup used for the experiments comprised of a 2 electrode cell [41], with one $\mathrm{Ag} \mid \mathrm{AgCl}$ electrode in the organic phase and one in the aqueous phase. The cell utilised in these experiments is shown in Scheme 1, where $\mathrm{x}$ refers to the concentration of $\mathrm{Mb}$ or $\mathrm{TEA}^{+}$. All potentials are reported with respect to the experimentally-used reference electrodes.

\section{Results and discussion}

\subsection{Cyclic voltammetry of Myoglobin.}

The electrochemical behaviour of $\mathrm{Mb}$ at the ITIES was investigated using cyclic voltammetry. Figure 1(a) shows the voltammograms obtained when scanning from $0.0 \mathrm{~V}$ to $1.0 \mathrm{~V}$ relative to the $\mathrm{Ag} \mid \mathrm{AgCl}$ electrodes. The protein's iso-electric point is 7.3 [2] and hence it is positively charged at $\mathrm{pH} 2$ and assumed to be fully protonated, in which case it has a charge of +32 , based on its amino acid sequence. The forward scan shows an increase in current (at ca. $+0.75 \mathrm{~V}$ ) in the presence of the protein as the scan approaches the end of the electrochemical window. This is a feature of facilitated transfer of the organic phase anion in the presence of adsorbed positively-charged protein at the ITIES [27, 28]. Although it is difficult to distinguish a transfer wave from background electrolyte transfer so close to the limit of the potential window, it can still be seen that the forward-scan current increases with the concentration of $\mathrm{Mb}$ present in the aqueous phase. The reverse scan shows a well-defined peak at 0.68 $\mathrm{V}$, which is attributed to desorption of the protein from the interface, as seen in previous studies with other proteins [27]. Figure 1(b) shows the peak currents from the reverse peaks in the concentration range $1-6 \mu \mathrm{M} \mathrm{Mb}$. Blank scans (i.e. zero $\mathrm{Mb}$ present in the aqueous phase) were recorded in between scans with $\mathrm{Mb}$ present in order to ensure that no protein remained absorbed on the interface and 
carried over from one experiment to the next. These blank scans were featureless in the potential regions where $\mathrm{Mb}$ exhibited voltammetric behaviour. In the $1-6 \mu \mathrm{M}$ concentration range there was a linear response between the reverse peak current and the concentration of $\mathrm{Mb}$ (correlation coefficient $\mathrm{R}=0.9968$ ). The surface coverage of $\mathrm{Mb}$ at the $\mu$ ITIES array can be determined from the charge under the reverse scan peaks using equation 1 [42].

$$
Q=z_{i} F A \Gamma
$$

Here, $Q$ is the charge corresponding to the desorption peak $(\mathrm{C}), z_{i}$ is the charge on the protein, $F$ is Faraday's constant $\left(\mathrm{C} \mathrm{mol}^{-1}\right), A$ is the total geometric area of the microinterfaces $\left(\mathrm{cm}^{2}\right)$ in the array, and $\Gamma$ is the surface coverage. The charges for the reverse peaks in Figure 1(a) correspond to surface coverages in the region of $10-50 \mathrm{pmol} \mathrm{cm}^{-2}$. The surface coverage varied with aqueous phase concentration of $\mathrm{Mb}$ similar to that of the peak current, in that no saturation effect was observed in the concentration range studied. The adsorption of $\mathrm{Mb}$ at the ITIES was investigated previously by Girault's group using optical second harmonic generation [43]. The surface area occupied by a single $\mathrm{Mb}$ molecule was taken from its crystallographic data and assumed to be $10 \mathrm{~nm}^{2}$ [44]. It was shown that a full monolayer coverage corresponds to $10^{17}$ molecules $/ \mathrm{m}^{2}$ (or $1.66 \times 10^{-11} \mathrm{~mol} \mathrm{~cm}{ }^{-2}$ ). The surface coverage data obtained from Figure 1(a) thus correspond to between 0.6 of a monolayer (10 pmol cm$)^{-2}$ and 2.9 monolayers $\left(50 \mathrm{pmol} \mathrm{cm}{ }^{-2}\right)$. These results are consistent with the finding that a multilayer of haemoglobin was formed at the liquid-liquid interface during the course if a single cyclic voltammetric scan [38]. It should be noted also that the experimental data obtained from cyclic voltammetry are not obtained at equilibrium, unlike the optical SHG studies[43] and much longer adsorption times may be needed to achieve surface saturation and equilibration.

\subsection{Scan rate studies.}


To investigate the nature of the processes (diffusion, adsorption) occurring at the interface, cyclic voltammetry at a fixed $\mathrm{Mb}$ concentration $(5 \mu \mathrm{M})$ was carried out with varying scan rates, in the range $5-75 \mathrm{mVs}^{-1}$ (Figure 2). The reverse peak current showed a linear response to scan rate $(\mathrm{R}=0.997)$. This dependence of the reverse peak current on scan rate indicates that the behaviour is not diffusioncontrolled but is due to desorption of the protein from the interface. Although the peak current increased with scan rate, at the higher scan rates the peaks became broader and less distinguishable from the background electrolyte transfer and capacitive charging current and hence was more difficult to measure the peak magnitude. As a result, the current versus scan rate plot exhibited a large intercept on the current axis, of ca. $1 \mu \mathrm{A}$. These results agree with the previous model proposed for a facilitated ion transfer (FIT) mechanism for protein detection at the ITIES [26, 27]. The protein adsorbs to the interface and facilitates the transfer of the organic phase anion resulting in the broad forward wave and the formation of a protein-organic phase anion complex at the aqueous side of the interface. On the reverse scan, the complex dissociates, with accompanying protein desorption and anion reverse transfer to the organic phase, resulting in the reverse peak recorded in the voltammogram.

\subsection{Influence of the aqueous phase ionic strength.}

The effects of varying ionic strength on the voltammetry of $\mathrm{Mb}$ at a fixed concentration $(5 \mu \mathrm{M})$ was investigated. The ionic strength was varied by changing the concentration of $\mathrm{LiCl}$ in the aqueous phase from $1 \mathrm{mM}$ to $10 \mathrm{mM}$ to $100 \mathrm{mM}$. The aqueous phase was maintained at $\mathrm{pH} 2$ by using $10 \mathrm{mM} \mathrm{HCl}$ in addition to the variable $\mathrm{LiCl}$ concentrations. The ionic strengths were calculated from equation (2), where $I_{c}$ is the total ionic strength of the electrolyte solution $(\mathrm{M}), c_{i}$ is the molar concentration of the ion $i(\mathrm{M})$, and $z_{i}$ is the charge on that ion $i$. The sum is then taken over all ions in solution.

$$
I_{c}=\frac{1}{2} \sum_{i}^{n} c_{i} Z_{i}^{2}
$$


The corresponding ionic strengths for 1,10 and $100 \mathrm{mM} \mathrm{LiCl}$ solutions in a background of $10 \mathrm{mM}$ $\mathrm{HCl}$ were $0.011,0.02$ and $0.11 \mathrm{M}$, respectively. Figure 3 shows the resulting cyclic voltammograms related to increasing ionic strength of the aqueous phase. Previous work at the ITIES indicated that increasing ionic strength results in a marked decrease in the magnitude of peaks due to the presence of a protein [26], in that case hen egg white lysozyme. It was suggested that the protein was further solvated by the ions in solution and this caused a decrease in protein concentration available to adsorb at the interface. Interestingly, the results presented here show that as the ionic strength increases (Figure 3(a-c)), the peaks attributed to protein adsorption/desorption become sharper and better defined as well as producing greater currents. A possible reason for the increase in the peak currents is the salting out effect [45]. This effect is used to precipitate proteins in solutions by adjusting the salt concentration. The effects of various ions on protein stability is characterised by the Hofmeister series [46]. Salt ions are categorised according to whether they denature or stabilise a protein [47]. At high salt concentrations, protein-protein interactions become favourable over electrostatic repulsion and this is the driving force for precipitation [48, 49] and aggregation [50]. It has also been reported that at low $\mathrm{pH}$, protein-protein interactions become more favourable [51]. It is likely that this combination of effects served to pre-concentrate the protein at or near the interface at the highest LiCl concentration. It was noted that during the preparation of the $\mathrm{LiCl} / \mathrm{Mb}$ solutions at higher concentrations of $\mathrm{LiCl}$, the protein tended to form a precipitate and aggregate in the aqueous solution. While this may improve the qualitative ability to detect $\mathrm{Mb}$ at the ITIES, it has implications for using the data obtained as a quantitative measurement of the protein present. As the protein solution is no longer homogeneous, representative sampling becomes a problem.

\subsection{Effects of the aqueous phase $\mathrm{pH}$.}

The mechanism of FIT of the hydrophobic organic phase anion by the cationic protein species in the aqueous phase can be further validated by investigating the influence of the aqueous phase $\mathrm{pH}$. Figure 
4 shows the cyclic voltammetry of $9 \mu \mathrm{M} \mathrm{Mb}$ when the aqueous phase is adjusted to $\mathrm{pH}$ values of 7,12 and 2, (Figures 4 (a), (b) and (c), respectively). The voltammograms show that the ion transfer process only occurs when the protein is in a cationic state (in an aqueous phase whose $\mathrm{pH}$ is lower than the protein's pI); no ion-transfer response was seen at the $\mathrm{pI}$ or above. This trend is typical of what has been seen in previous studies at the ITIES [26, 28]. Although the CVs in the absence and presence of $\mathrm{Mb}$ at aqueous phase $\mathrm{pH}$ values greater than the protein's $\mathrm{pI}$ are similar, there is a slight shift in the capacitive current (Figure 4(b)) which may be a result of adsorption. But no peaks that can be associated with cation or anion transfer within the available potential window were observed.

\subsection{Influence of Myoglobin on TEA ${ }^{+}$transfer at the $\mu$ ITIES array.}

Further evidence for adsorption/desorption of $\mathrm{Mb}$ at the interface can be seen by comparing voltammograms in the presence and absence of the tetraethylammonium $\left(\mathrm{TEA}^{+}\right)$cation. Simple ion transfer of an ion such as $\mathrm{TEA}^{+}$at the $\mu$ ITIES array results in a steady-state current on the forward sweep and a peak-shaped current on the reverse sweep. The asymmetric voltammograms are the result of radial and linear diffusion profiles during the forward and reverse scans, respectively [38, 52, 53]. Figure 5(a) shows the voltammogram for $\mathrm{TEA}^{+}$transfer in the absence of Mb. The steady-state current for $\mathrm{TEA}^{+}$is $1.8 \mathrm{nA}$, with a half-wave potential of $0.68 \mathrm{~V}$. The steady-state forward response results from radial diffusion to the interface from the aqueous phase and the peak-shaped reverse response is due to linear diffusion of the analyte molecules, from the organic phase held within the membrane micropores, back to the aqueous phase. In the presence of aqueous phase $\mathrm{Mb}$, the steady-state response to $\mathrm{TEA}^{+}$is disrupted on the forward scan (Figure 5(b)) once a potential has been reached that is sufficient to induce adsorption of the protein $(>0.6 \mathrm{~V})$. This results in a decreased steady state current for $\mathrm{TEA}^{+}$transfer of $0.7 \mathrm{nA}$. This drop in current indicates that the transfer of the $\mathrm{TEA}^{+}$is affected by protein adsorbed at the interface, but also that Mb adsorption is less disruptive than lysozyme [27, 54]. The reverse peak current for $\mathrm{TEA}^{+}$back-transfer was decreased in the presence of $\mathrm{Mb}$ from $1.8 \mathrm{nA}$ to 
$1.5 \mathrm{nA}$, indicating that less $\mathrm{TEA}^{+}$was transferred into the organic phase due to adsorbed $\mathrm{Mb}$. When the voltammogram for $\mathrm{TEA}^{+}$transfer (Figure 5(a)) is compared to the analogous voltammogram in the presence of protein (Figure 5 (b)) it can clearly be seen that the steady-state current on the forward sweep is diminished, while the reverse peak current is also decreased, albeit less substantially. This indicates that although the adsorbed $\mathrm{Mb}$ disrupts ion transfer at the interface, it does not however stop ion transfer completely, unlike the case observed with lysozyme $[27,54]$. This phenomenon may be a result of different adsorptive strengths for different proteins at the gelled ITIES.

\subsection{Effect of aqueous solution on Myoglobin conformation.}

$\mathrm{UV} / \mathrm{V}$ is absorbance spectroscopy was used to investigate whether there were any conformational changes within the Mb structure due to the effects of the aqueous phase solutions used in the above studies. UV/Vis absorbance spectroscopy can be used to investigate directly the effect of the environment on $\mathrm{Mb}$ tertiary structure because the absorbance spectrum of the haem group is directly affected by its physical environment [55]. Five different aqueous solutions were used in the preparation of sample solutions: purified $\mathrm{H}_{2} \mathrm{O}, 10 \mathrm{mM} \mathrm{LiCl}, 10 \mathrm{mM}$ PBS, $10 \mathrm{mM} \mathrm{HCl}$ and $10 \mathrm{mM}$

$\mathrm{LiCl}$ at $\mathrm{pH}$ 2. The wavelength range scanned in the UV/Vis absorbance experiments was chosen to include the Soret band at $c a .410 \mathrm{~nm}$ [56], which is due to the haem centre, and also the band at 280 $\mathrm{nm}$, which is due to the aromatic amino acids [57]. It can be seen from Figure 6 that the Soret band is diminished in the presence of an acid solution $(10 \mathrm{mM} \mathrm{LiCl}$ at $\mathrm{pH} 2$ and $10 \mathrm{mM} \mathrm{HCl})$. However, in the higher pH solutions (no added acid), the Soret band remains unaffected. This is indicative of some denaturation/unfolding of the protein tertiary structure by the acidic aqueous phase electrolyte solution [55], although the extent of this process cannot be known from the UV/Vis spectra alone. The band due to the aromatic amino acids remains relatively unaffected in all aqueous solutions studied.

\section{Conclusions}


The aim of this work was to investigate whether myoglobin was electroactive at the $\mu$ ITIES array, to characterize its behaviour and to compare it to the behaviour of other proteins at this interface. The results indicate that the peak currents produced for myoglobin have a linear response to concentration in the range of $1-6 \mu \mathrm{M}$. The basis of the detection mechanisms was investigated by varying the voltammetric scan rate, the aqueous phase $\mathrm{pH}$ and by examining the influence of the presence of myoglobin on the ion transfer voltammetry of TEA ${ }^{+}$. Based on the results obtained, the detection of $\mathrm{Mb}$ is attributed to an interfacial adsorption/desorption process accompanied by organic phase anion transfer and association with the cationic protein. It was shown that the behaviour of myoglobin was similar to previously studied proteins, lysozyme, haemoglobin and insulin, in terms of its FIT mechanism and dependence on the cationic state of the protein in the aqueous phase. The reverse voltammetric peak showed a dependence on scan rate which indicates a desorption process. The appearance of a peak is dependent on the aqueous phase $\mathrm{pH}$ in that the protein needs to be in a charged state below the pI for detection to be possible. However, the need for the positively-charged protein species in the present system requires the use of low $\mathrm{pH}$ aqueous solutions, which have been shown, by the UV/Vis spectrophotometry of the myoglobin solutions, to denature the protein structure. The increased peak currents observed with increased $\mathrm{LiCl}$ concentration can best be explained if viewed as a type of pre-concentration step, with the formation of protein aggregates that accumulate on the interface. The results provide the basis for label-free detection of proteins at liquid-liquid interfaces by electrochemical methods.

\section{Acknowledgements}

This work was supported by Curtin University and the Western Australian Nanochemistry Research Institute. SOS thanks Curtin University for the award of a PhD scholarship via the Curtin Strategic International Research Scholarships scheme. The silicon microporous membranes used were a gift from Tyndall National Institute, Cork, Ireland. 


\section{References}

[1] Z. Samec, Pure Appl. Chem., 76 (2004) 2147.

[2] E. Blanco, J.M. Ruso, J. Sabin, G. Prieto, F. Sarmiento, Journal of Thermal Analysis and Calorimetry, 87 (2007) 211.

[3] J.C. Kendrew, G. Bodo, H.M. Dintzis, R.G. Parrish, H. Wyckoff, D.C. Phillips, Nature, 181 (1958) 662.

[4] T.D. Paulo, I.C.N. Diogenes, H.D. Abruna, Langmuir, 27 (2011) 2052.

[5] Rajesh, V. Sharma, V.K. Tanwar, S.K. Mishra, A.M. Biradar, Thin Solid Films, 519 (2010) 1167.

[6] E. Suprun, T. Bulko, A. Lisitsa, O. Gnedenko, A. Ivanov, V. Shumyantseva, A. Archakov, Biosens. Bioelectron., 25 (2010) 1694.

[7] B. McDonnell, S. Hearty, P. Leonard, R. O'Kennedy, Clinical Biochemistry, 42 (2009) 549.

[8] S.F. Melanson, M.J. Tanasijevic, Cardiovasc. Pathol., 14 (2005) 156.

[9] G. Herzog, S. O' Sullivan, J.S. Ellis, D.W.M. Arrigan, Sensor Letters, 9 (2011) 721.

[10] D.W.M. Arrigan, Analytical Letters, 41 (2008) 3233.

[11] G. Taylor, H.H.J. Girault, J. Electroanal. Chem., 208 (1986) 179.

[12] B. Liu, M.V. Mirkin, Electroanalysis, 12 (2000) 1433.

[13] S.J. Liu, Q. Li, Y.H. Shao, Chem. Soc. Rev., 40 (2011) 2236.

[14] M.D. Scanlon, D.W.M. Arrigan, Electroanalysis, 23 (2011) 1023.

[15] M.D. Scanlon, J. Strutwolf, A. Blake, D. lacopino, A.J. Quinn, D.W.M. Arrigan, Anal. Chem., 82 (2010) 6115.

[16] J.A. Campbell, H.H. Girault, J. Electroanal. Chem., 266 (1989) 465.

[17] V.J. Cunnane, D.J. Schiffrin, D.E. Williams, Electrochim Acta, 40 (1995) 2943.

[18] R. Zazpe, C. Hibert, J. O'Brien, Y.H. Lanyon, D.W.M. Arrigan, Lab on a Chip, 7 (2007) 1732.

[19] G. Herzog, D.W.M. Arrigan, Analyst, 132 (2007) 615.

[20] J.D. Guo, Y. Yuan, S. Amemiya, Anal. Chem., 77 (2005) 5711.

[21] P. Jing, Y. Kim, S. Amemiya, Langmuir, 25 (2009) 13653.

[22] A. Trojánek, J. Langmaier, E. Samcová, Z. Samec, J. Electroanal. Chem., 603 (2007) 235.

[23] Y. Yuan, S. Amemiya, Anal. Chem., 76 (2004) 6877.

[24] G. Herzog, V. Kam, D.W.M. Arrigan, Electrochim. Acta, 53 (2008) 7204.

[25] G. Herzog, P. Eichelmann-Daly, D.W.M. Arrigan, Electrochem. Commun., 12 (2010) 335.

[26] M.D. Scanlon, E. Jennings, D.W.M. Arrigan, Phys. Chem. Chem. Phys., 11 (2009) 2272.

[27] M.D. Scanlon, J. Strutwolf, D.W.M. Arrigan, Phys. Chem. Chem. Phys., 12 (2010) 10040.

[28] F. Kivlehan, Y.H. Lanyon, D.W.M. Arrigan, Langmuir, 24 (2008) 9876.

[29] G. Herzog, B. McMahon, M. Lefoix, N.D. Mullins, C.J. Collins, H.A. Moynihan, D.W.M. Arrigan, J.

Electroanal. Chem., 622 (2008) 109.

[30] A. Berduque, R. Zazpe, D.W.M. Arrigan, Analytica Chimica Acta, 611 (2008) 156.

[31] J.A. Ribeiro, I.M. Miranda, F. Silva, C.M. Pereira, Phys. Chem. Chem. Phys., 12 (2010) 15190.

[32] F. Kivlehan, M. Lefoix, H.A. Moynihan, D. Thompson, V.I. Ogurtsov, G. Herzog, D.W.M. Arrigan,

Electrochim Acta, 55 (2010) 3348.

[33] M. Shinshi, T. Sugihara, T. Osakai, M. Goto, Langmuir, 22 (2006) 5937.

[34] T. Osakai, A. Shinohara, Anal. Sci., 24 (2008) 901.

[35] T. Osakai, Y. Yuguchi, E. Gohara, H. Katano, Langmuir, 26 (2010) 11530.

[36] J.S. Ellis, S.Q. Xu, X. Wang, G. Herzog, D.W.M. Arrigan, M. Thompson, Bioelectrochemistry, 79 (2010) 6.

[37] R.A. Hartvig, M.A. Mendez, M. van de Weert, L. Jorgensen, J. Ostergaard, H.H. Girault, H. Jensen, Anal. Chem., 82 (2010) 7699.

[38] J. Strutwolf, M.D. Scanlon, D.W.M. Arrigan, Analyst 134 (2009) 148.

[39] M.D. Scanlon, G. Herzog, D.W.M. Arrigan, Anal. Chem., 80 (2008) 5743.

[40] H.J. Lee, P.D. Beattie, B.J. Seddon, M.D. Osborne, H.H. Girault, J. Electroanal. Chem., 440 (1997) 73. 
[41] T. Osakai, T. Kakutani, M. Senda, B Chem Soc Jpn, 57 (1984) 370.

[42] J. Wang, Analytical electrochemistry, 2nd ed (2000) 209.

[43] J. Perrenoud-Rinuy, P.F. Brevet, H.H. Girault, Phys Chem Chem Phys, 4 (2002) 4774.

[44] R. Maurus, R. Bogumil, N.T. Nguyen, A.G. Mauk, G. Brayer, Biochemical Journal, 332 (1998) 67.

[45] Y.F. Yano, T. Uruga, H. Tanida, Y. Terada, H. Yamada, J. Phys. Chem. Lett., 2 (2011) 995.

[46] R.A. Curtis, J. Ulrich, A. Montaser, J.M. Prausnitz, H.W. Blanch, Biotechnol. Bioeng., 79 (2002) 367.

[47] R.L. Baldwin, Biophysical Journal, 71 (1996) 2056.

[48] D.E. Kuehner, J. Engmann, F. Fergg, M. Wernick, H.W. Blanch, J.M. Prausnitz, J. Phys. Chem. B, 103 (1999) 1368.

[49] A.C. Dumetz, A.M. Snellinger-O'Brien, E.W. Kaler, A.M. Lenhoff, Protein Sci., 16 (2007) 1867.

[50] Y.J. Zhang, P.S. Cremer, Proc. Natl. Acad. Sci. U. S. A., 106 (2009) 15249.

[51] A.C. Dumetz, A.M. Chockla, E.W. Kaler, A.M. Lenhoff, BBA-Proteins Proteomics, 1784 (2008) 600.

[52] J.A. Campbell, A.A. Stewart, H.H. Girault, Journal of the Chemical Society, Faraday Transactions 1: Physical Chemistry in Condensed Phases, 85 (1989) 843.

[53] Y. Shao, M.D. Osborne, H.H. Girault, J. Electroanal. Chem., 318 (1991) 101.

[54] E. Alvarez de Eulate, D.W.M. Arrigan, Anal. Chem., 84 (2012) 2505.

[55] A.B. Anderson, C.R. Robertson, Biophysical Journal, 68 (1995) 2091.

[56] C. Rimington, Biochem J, 75 (1960) 620.

[57] C.M. Jones, Chem. Educator, 4 (1999) 94. 


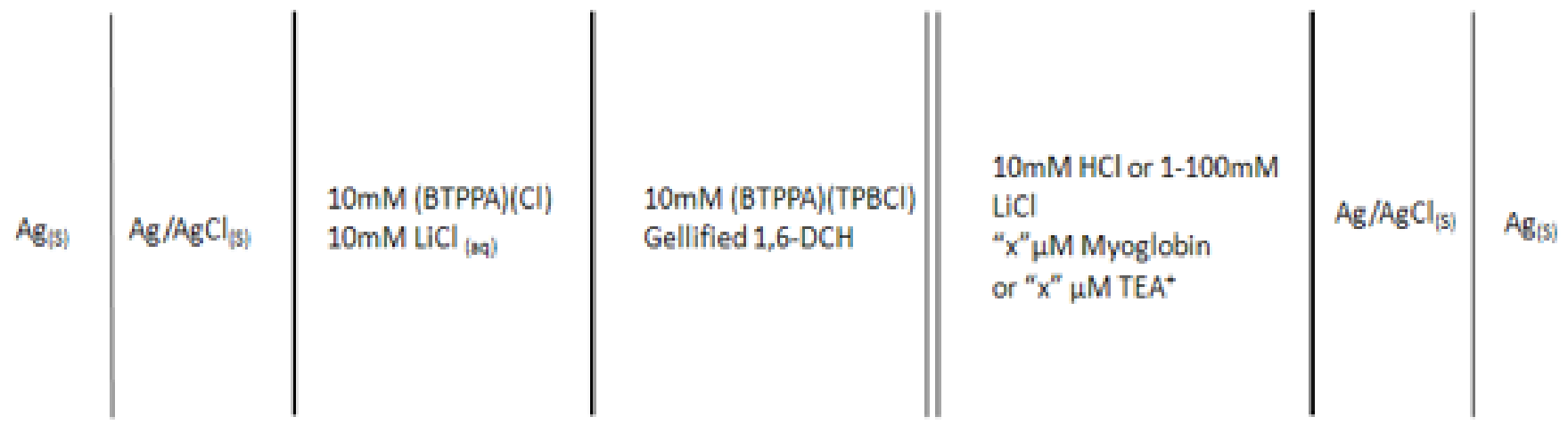

Scheme 1: electrochemical cell employed in these experiments 

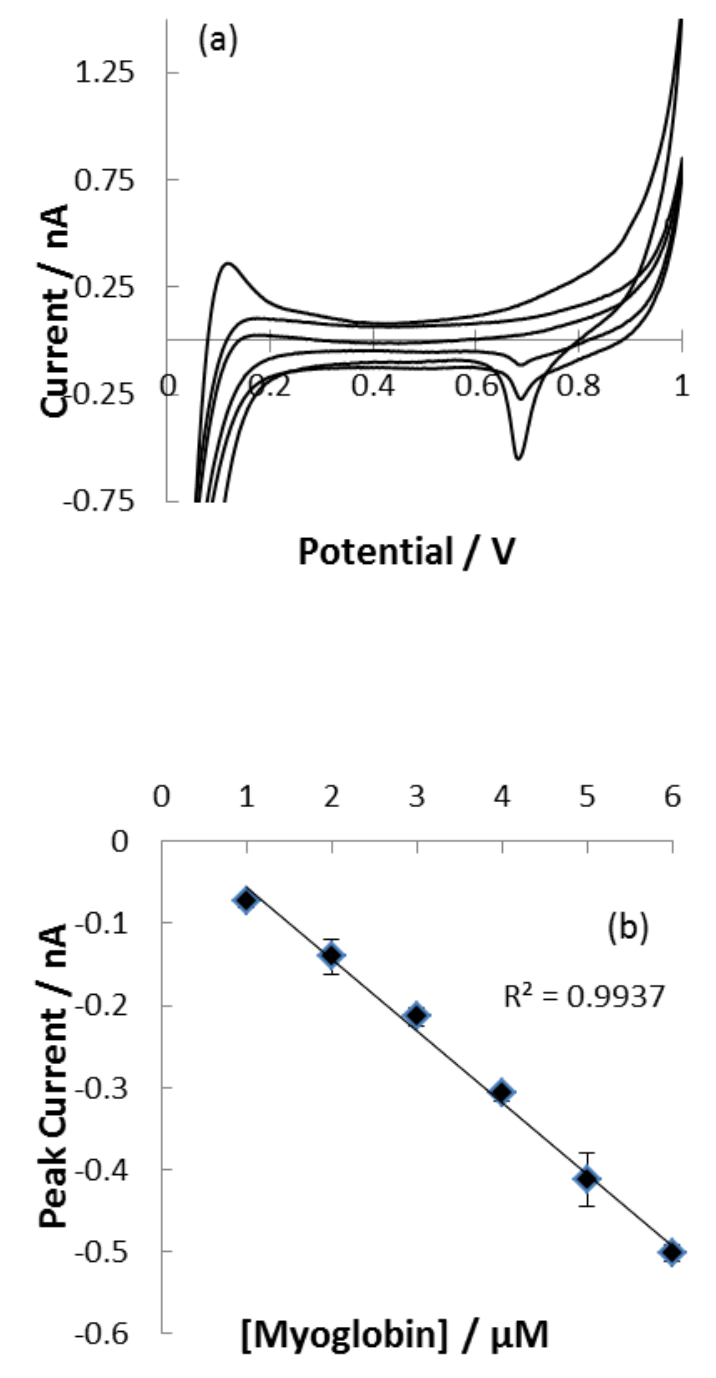

Figure 1. (a) CVs of 1,3 and $6 \mu \mathrm{M} \mathrm{Mb}$, scan rate $5 \mathrm{mVs}^{-1}$. (b) Plot of reverse peak current versus myoglobin concentration. The electrochemical cell is as outlined as in scheme 1 . 


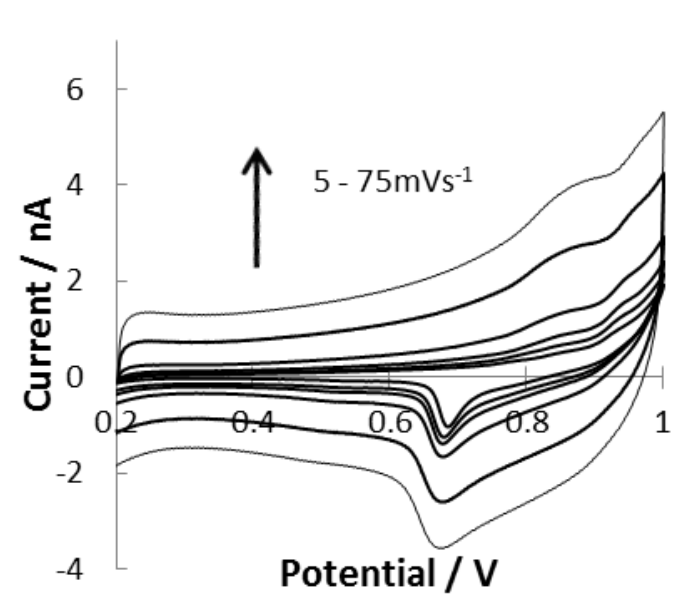

Figure 2. $\mathrm{CVs}$ of $5 \mu \mathrm{M} \mathrm{Mb}$, scan rates of $5,10,15,25,50$ and $75 \mathrm{mVs}^{-1}$. The electrochemical cell is as outlined in scheme 1. 


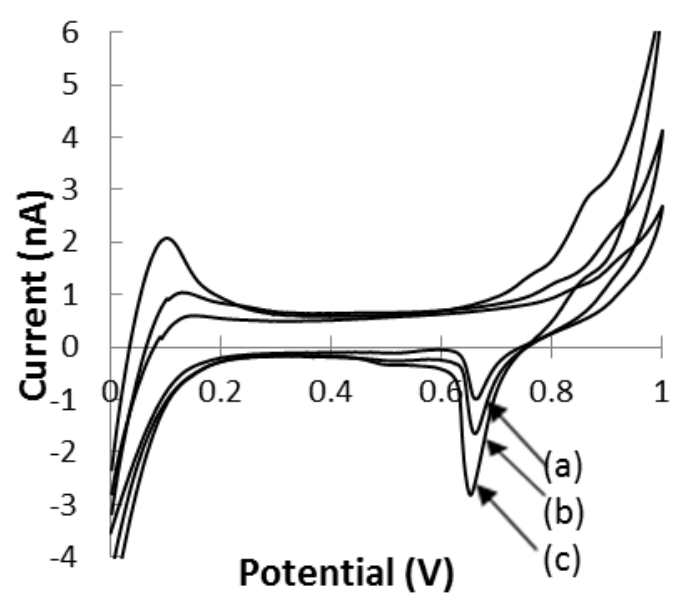

Figure 3. $\mathrm{CV}$ of $5 \mu \mathrm{M} \mathrm{Mb}$ with increasing ionic strength of the aqueous phase. (a) (b) and (c) correspond to 1,10 and $100 \mathrm{mM} \mathrm{LiCl}$ in $10 \mathrm{mM} \mathrm{HCl}$, respectively. The electrochemical cell is as outlined in scheme 1. 

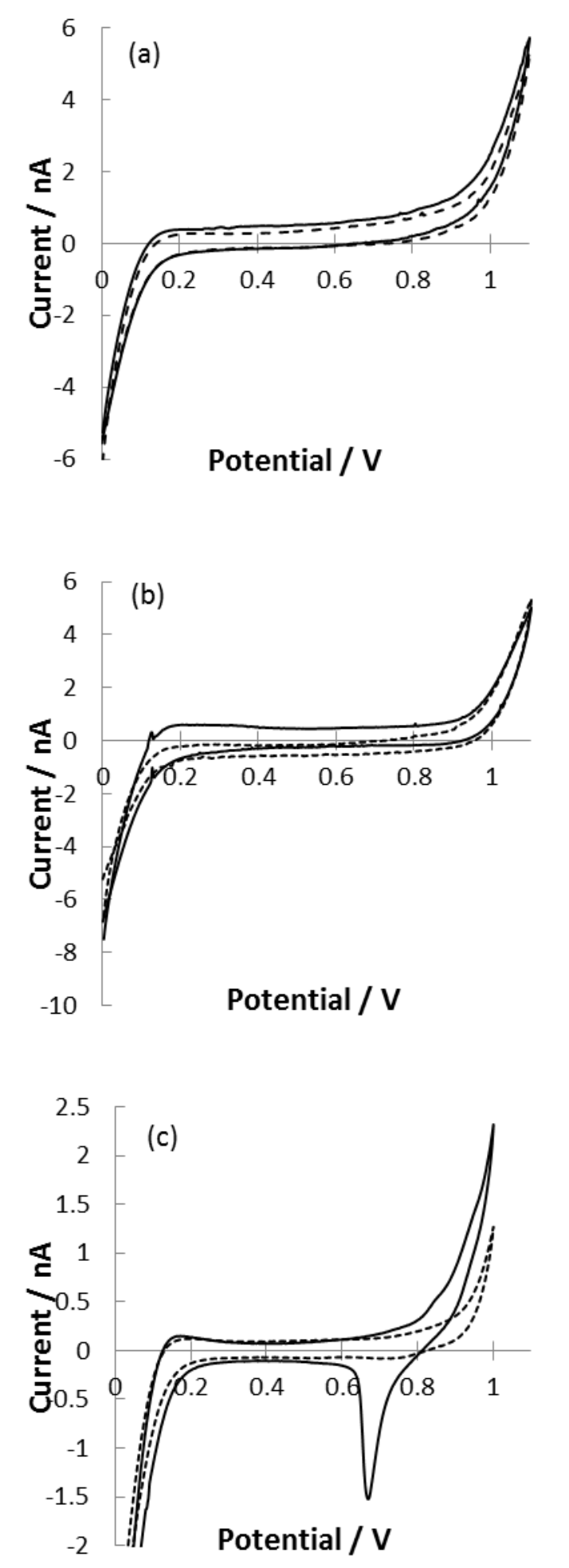

Figure 4. $\mathrm{CV}$ of $9 \mu \mathrm{M} \mathrm{Mb}$ in (a) $\mathrm{pH} 7$, (b) $\mathrm{pH} 12$, (c) $\mathrm{pH} 2$ aqueous phase, scan rate $5 \mathrm{mVs}^{-1}$. The blank scan (absence of $\mathrm{Mb}$ ) is represented by the dashed line and the $9 \mu \mathrm{M} \mathrm{Mb}$ by the solid line. The electrochemical cell is as outlined in scheme 1. 

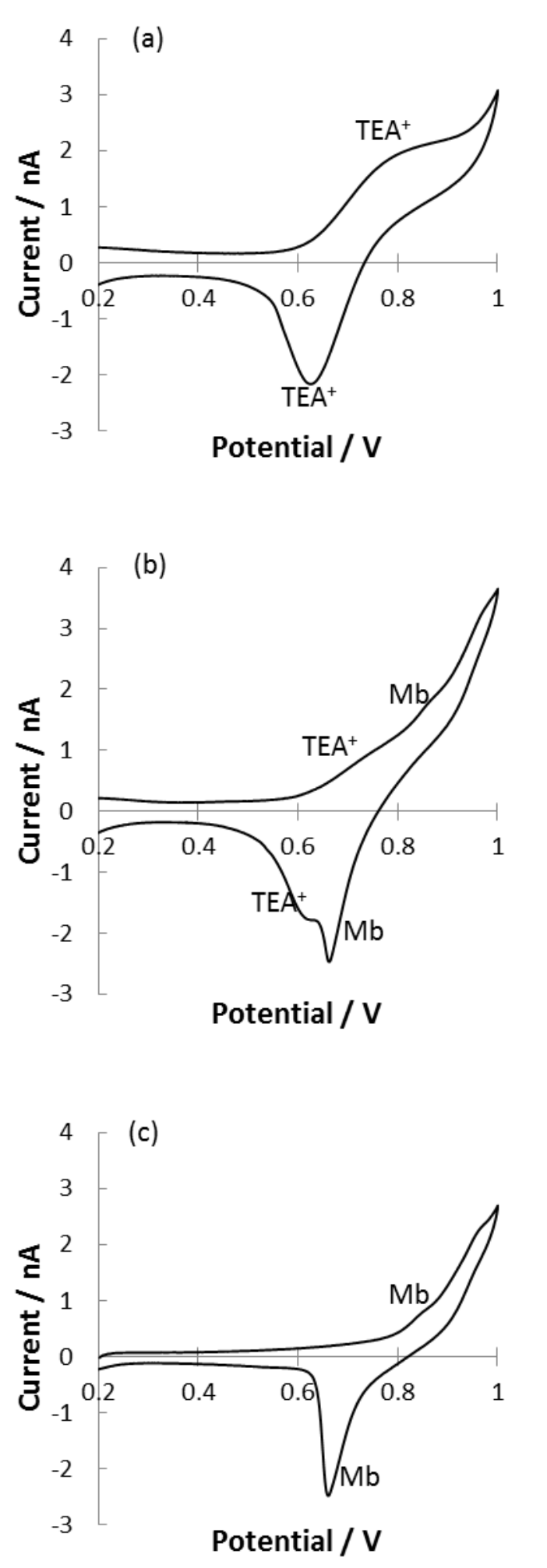

Figure 5. (a) $\mathrm{CV}$ of $15 \mu \mathrm{M} \mathrm{TEA}^{+}$, (b) $\mathrm{CV}$ of $15 \mu \mathrm{M} \mathrm{TEA}^{+}$plus $9 \mu \mathrm{M} \mathrm{Mb}$, and (c) $\mathrm{CV}$ of $9 \mu \mathrm{M} \mathrm{Mb}$, scan rate $5 \mathrm{mVs}^{-1}$. On the voltammograms, the labels $\mathrm{TEA}^{+}$and $\mathrm{Mb}$ indicate features attributed to $\mathrm{TEA}^{+}$transfer and $\mathrm{Mb}$ adsorption/desorption, respectively. The electrochemical cell is as outlined in scheme 1 . 


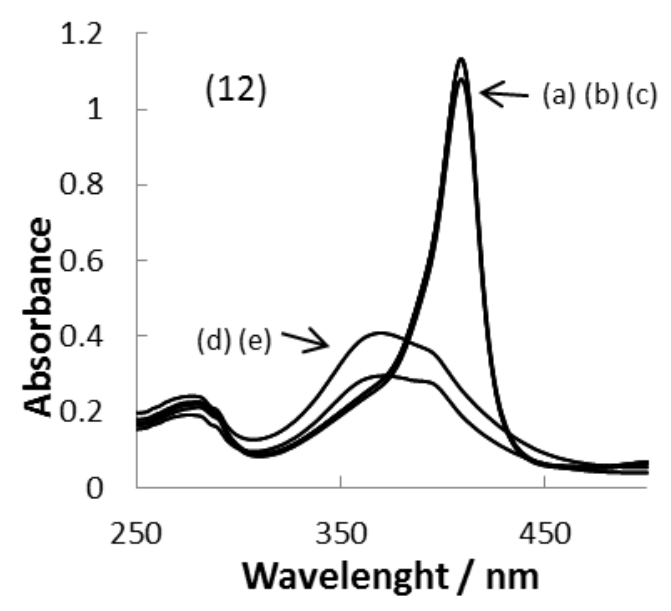

Figure 6. UV/Vis absorbance spectra of $10 \mu \mathrm{M} \mathrm{Mb}$ in (a) $\mathrm{H}_{2} \mathrm{O}$, (b) $10 \mathrm{mM} \mathrm{LiCl}$ and (c) $10 \mathrm{mM}$ phosphate buffered saline (PBS). (d) and e) correspond to $10 \mu \mathrm{M} \mathrm{Mb}$ in aqueous solutions of $10 \mathrm{mM}$ $\mathrm{LiCl} \mathrm{pH} 2$ and $10 \mathrm{mM} \mathrm{HCl}$. 